\title{
A TERMOGRÁFIA MÉRÉSTECHNIKAI NEHÉZSÉGEINEK ELEMZÉSE
}

\section{A REVIEW OF DIFFICULTIES IN THE MEASURING TECHNOLOGIES OF THERMOGRAPHY}

\author{
Haraszti Ferenc \\ Óbudai Egyetem, Bánki Donát Gépész és Biztonságtechnikai Mérnöki Kar, Gépészeti és Biztonságtudományi, \\ Budapest, Magyarország, haraszti.ferenc@bgk.uni-obuda.hu
}

\begin{abstract}
Thermography, a non-contact measuring technology for determining temperature, is becoming more and more widespread nowadays. The use of this imaging method assumes simple usage, but for the declaration of appropriate and correct temperature values, a complex measurement routine and in-depth theoretical knowledge are essential. In my articles I will draw attention to the most important factors influencing measurement, both from a theoretical and practical point of view.
\end{abstract}

Keywords: thermography, thermographic camera, measuring technology.

\section{Összefoglalás}

A termográfia mint érintésmentes hőmérséklet-meghatározó módszer napjaink elterjedőben lévő méréstechnikája. E képalkotó rendszer használata ma már egyszerü használatot feltételez, de a megfelelően és helyesen meghatározott hőmérsékletértékek deklarálásához nagy mérési rutin és az elméleti tudás nélkülözhetetlen. Cikkemben a legfontosabb mérést befolyásoló tényezőkre kívánom felhívni a figyelmet elméleti és gyakorlati szempontból egyaránt.

Kulcsszavak: termográfia, hökamera, méréstechnika.

\section{Bevezetés}

A mai modern műszaki diagnosztikai vizsgálatok elképzelhetetlenek érintés nélküli hőmérsékletmérés nélkül. A nagy intenzitással folyó kutatások, a sorozatgyártás nagyságrendekkel elérhetőbbé tette a termokamera jelenlétét az időszakos állapotvizsgálatok terén. A felhasználóbarát kezelhetőség, a könnyen állítható mérési paraméterek rendkívül egyszerü mérési metódusokat sugallnak az átlagfelhasználó számára. Azonban a termográfia mint képalkotó mérési eljárás megfelelően elsajátított elméleti és gyakorlati tudás hiányában szinte minden esetben rossz, kiértékelhetetlen, hibás hőmérsékleti eredményeket produkál. Biztonságtechnikai, munkavédelmi szempontból ez élet- és közveszélyes állapotokat generál.

\section{A termográfia alapjai}

Az infrasugárzáson alapuló hőmérsékletmérés, illetve a hőkamerás mérési módszer a testek hősugárzó képességétől függ. A hőmérsékleti sugárzás az a folyamat, amely az anyag hőmozgása miatt elektromágneses hullámokat bocsát ki magából. Ennek az energiának a nagy része másik testre átvetülve emittálódhat vagy reflektálódhat, továbbá transzmittálódhat is [1, 2]. Ha a vizsgált darabra érkező sugárzást az maradék nélkül elnyeli, akkor abszolút fekete testről beszélhetünk. Amennyiben teljes mértékben visszaverődik, akkor abszolút tükröződő testről, és hogyha a testen teljes mértékben áthalad, akkor átlátszó anyagról beszélhetünk. Az energiamegmaradás törvényének szemszögéből vizsgálva a sugárzási paramétereket, az alábbi összefüggést állapíthatjuk meg: 


$$
\varepsilon_{\lambda}+\rho_{\lambda}+\tau_{\lambda}=1
$$

ahol:

$\varepsilon_{\lambda}$ - emissziós tényező;

$\rho_{\lambda}$-reflexiós tényező;

$\tau_{\lambda}$ - transzmissziós tényező.

1. táblázat. Anyagok fizikai jellemzői

\begin{tabular}{|l|c|c|}
\hline \multicolumn{1}{|c|}{ Anyag } & Tényező & Összefüggés \\
\hline Fekete test & $\varepsilon=1$ & $\tau=0, \rho=0$ \\
\hline Tökéletes tükör & $\rho=1$ & $\varepsilon=0, \tau=0$ \\
\hline Tökéletes ablak & $\tau=1$ & $\varepsilon=0, \rho=0$ \\
\hline Nem átlátszó test & $\tau=0$ & $\varepsilon^{+} \rho=1$ \\
\hline
\end{tabular}

A táblázatból (1. táblázat) ) levonható gyakorlati következtetés szerint a tökéletes tükör és a tökéletes ablak hődetektoros technikával nem mérhető, hiszen számottevő sugárzást nem bocsátanak ki magukból. Anyagi minőségük nem teszi lehetővé felületük hőmérsékletének termográfiás meghatározását. Ezek az anyagok viszont a méréstechnikában a fenti tulajdonságaiknak köszönhetően széles körben alkalmazásra kerülnek.

\subsection{A sugárzás alaptörvénye}

A hősugárzásnak mint elektromágneses hullámterjedésnek közvetítő közegre nincs szüksége. A hősugárzás alaptörvénye a Stefan-Boltzmann-törvény [3]:

$$
E_{(f)}(T)=\sigma \times T^{4}
$$

ahol:

$E_{(f)} \quad$ - fekete test emissziós képessége;

$\sigma$ - Stefan-Boltzmann-féle állandó $5,6710^{-8} \mathrm{~J} / \mathrm{m}^{2} \mathrm{~K}^{4}$;

$T$ - hőmérséklet [K].

A törvény szerint a $T$-hőmérsékletű fekete test egységnyi felülete által egységnyi idő alatt kisugárzott teljes energia arányos a test hőmérsékletének negyedik hatványával. Látható tehát, hogy idealizált esetben csak a fekete test képes az öszszes hőenergiát elnyelni és azt kisugározni. Ilyen a valóságban azonban nincs. A különböző anyagok más és más mértékben képesek az energiát emittálni. Minél inkább hasonlítanak az ideális fekete test tulajdonságaihoz, annál pontosabb mérést tesznek lehetővé. Ellenkező esetben korrigálnunk kell a mérési eredményünket.

\section{A mérést befolyásoló tényezők}

Méréseinket valós környezetben az ideálistól eltérve végezzük. A valódi testek hőkibocsátó (sugárzási) kapacitása, a mérés körülményei minden esetben befolyásolják termográfiai analízisünket. A legfontosabb paraméterek a következők:

- emissziós tényező, $\varepsilon<1$;

- mérőeszköz hullámhosssza

- mérési útszakasz jellemzői.

Ezek közül a legfontosabb az emissziós tényező. Helytelen megválasztása akár nagyságrendi hőmérséklet különbséget is okozhat. Feketeségi foknak is nevezik, és egyszerűen fogalmazva, a tárgy felületének sugárzási képességét fejezi ki. Mértéke az ideális sugárzótól való eltérést mutatja. Minden esetben függ a mérendő objektum felületének anyagától, érdességétől, a mérőeszköz (hőkamera) és a tárgy által bezárt szögtől [4, 5]. Befolyásolja hőmérsékletmérésünket a háttérés tárgyhőmérséklet is. Sokan a hődetektálást végzők közül nem veszik figyelembe a mérendő objektum környezetében elhelyezkedő tárgyak által sugárzott hő nagyságát. Ez a hő reflektálódik a tárgyunkon, megváltoztatva a termokamerába jutó infravörös sugárzás valódi mennyiségét. Ha az emissziós tényezőt is pontatlanul adtuk meg, a két hiba erősíti egymást. Az 1, 2. ábrákon villamosszekrény behúzótekercsének hibás hőmérséklet meghatározása látható. A háttérhőmérséklet $20^{\circ} \mathrm{C}$-al való eltérése és a fémes felület emissziójának alulbecsült (25\%) értéke $20,2^{\circ} \mathrm{C}$-os eltérést eredményezett.

Fémek esetén a hőmérséklet függvényében változó kristályszerkezet az, ami más és más emissziós tényezőt jelenthet [6, 7]. A 3. ábrán különböző fémek specifikus emissziós tényezőjét láthatjuk a tárgyfelület hőmérsékletének függvényében [8, 9].

A grafikonból jól látható, hogy az emissziós tényező változása csak magasabb hőmérsékleten számottevő. Ebben a tartományban viszont figye-

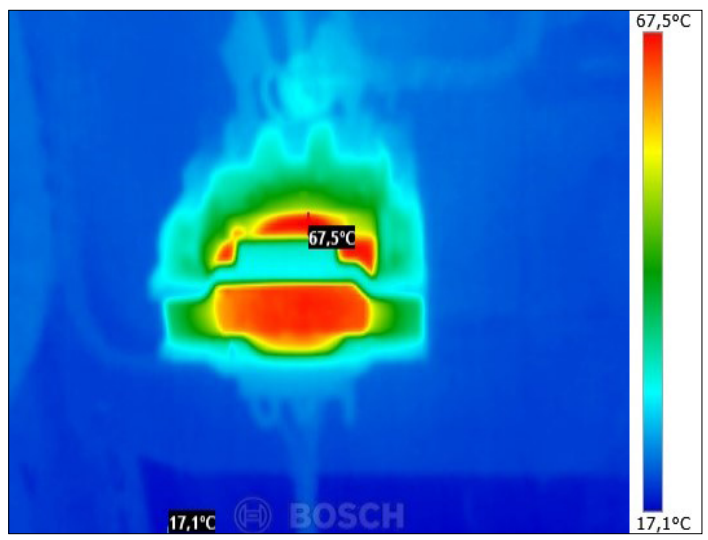

1. ábra. Behúzótekercs hőképe 


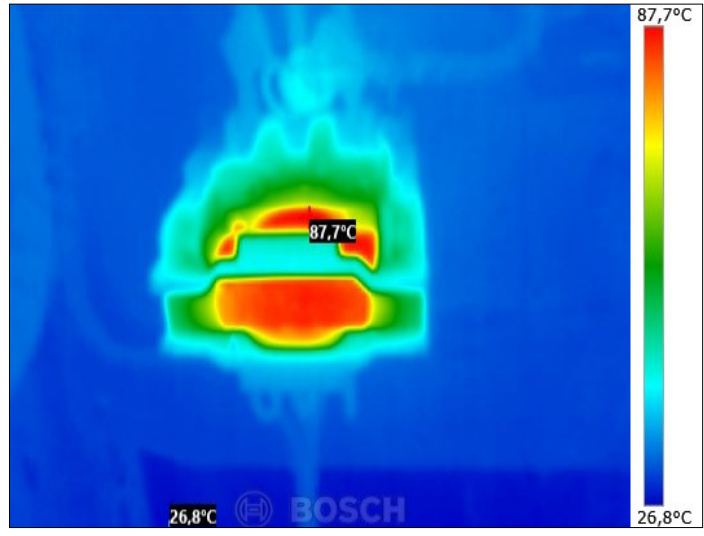

2. ábra. Behúzótekercs hőképe

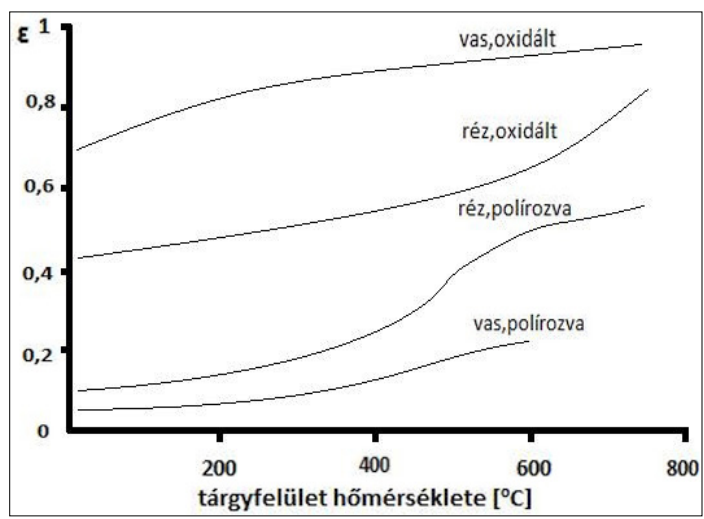

3. ábra. Különféle fémek emissziójának hőmérsékletfüggése

lembe kell vennünk a minél pontosabb hőanalízis miatt.

\subsection{Mérőeszköz hullámhossza}

Az érintés nélküli hőmeghatározás kivitelezése legfőképp a levegőn keresztül történik. Ez fizikai sajátságokat vet fel a mérőműszer kialakításában és a mérés folyamán. Többnyire három spektrális tartomány használata alakult ki. Beszélhetünk hosszú hullámú (8-14 $\mu \mathrm{m})$, középhullámú (3-5 $\mu \mathrm{m})$ és speciális esetekben rövidhullámú (1-2 $\mu \mathrm{m})$ hőkamerákról. A termográfiával foglalkozó szakember feladata eldönteni, melyik a legmegfelelőbb az adott feladat elvégzésére. Helytelenül választott méréstartomány hatást gyakorol a mérési eredményre. A gyakorlat azt mutatja, hogy a középhullámú mérőeszköz érzéketlen az alacsony hőmérsékletekre, viszont a magasabb $\left(400{ }^{\circ} \mathrm{C}\right)$ tartományban pontosabb mérést tesz lehetővé. Alacsony hőmérsékletek esetén célszerübb hosszú hullámú kamerát használni. Az ipari gyakorlatban azonban univerzálisan elterjedt hullámhossztartomány szintén a hosszú hullámú termokamera, alacsony és magas hőmérsékletek detektálására egyaránt. Kisebb korrekcióval megfelelően pontos eredményt kaphatunk például a villamosipar nem kívánatos melegedései terén. Speciális esetekben, amikor figyelembe kell vennünk a mérendő tárgy spektrális emisszióját, használhatjuk a rövidhullámon mérő hőkamerákat igen nagy hőmérsékleteken.

\subsection{Mérési útszakasz jellemzői}

Méréseinket - sok egyéb változó mellett - befolyásolja az infravörös sugárzás tárgytól a mérőműszerig megtett útja is. Ez az út, néhány kivételtől eltekintve, (vákuum) legtöbbször a levegő. A benne található szennyező anyagok: por, korom, füst, különféle vegyi anyagok hátrányosan befolyásolhatják méréseinket. Szintén hatással van az atmoszférában jelen lévő vízpára, oxigén, szén-dioxid, nitrogén, különféle szénhidrogének jelenléte. Torzíthatják eredményünket a zavaró sugárforrások, a levegő hőmérséklete is. Ezek a hátráltató tényezők már pár méterről is hátrányosan módosíthatják az átbocsátó képességet. Végül figyelembe kell vennünk a levegő fizikai sajátosságait, átviteli paramétereit is. Nem minden hullámhossztartományban van mód maximális intenzitású infravörös sugárzás detektálására. Számolt és kísérleti úton úgynevezett meghatározott atmoszferikus ablakhelyek alakulnak ki a légkörben, melyek jó átviteli tulajdonságokkal rendelkeznek. A gyártók ezekhez az ablakokhoz igazítják a különféle hullámhosszon előállított mérőberendezéseiket.

\section{Következtetések}

Cikkemben igyekeztem bemutatni a termográfiás hőmérséklet-meghatározás legalapvetőbb nehézségeit a teljesség igénye nélkül. A felhasználóbarát alkalmazhatóság, a látszólag triviális kezelhetőség mögött egy komplex és széles körü tudásbázist igénylő méréstechnikai eljárásról van szó. Pontos diagnosztikai vizsgálatokat csak hőtanfizikai felkészültség és évekig tartó üzemi méréstapasztalat útján lehet elsajátítani. Ma már az élet számos területén létjogosultságot nyert ez a technológia a villamosipartól kezdve katonai alkalmazásokon át az egészségügyig. Fontos tehát a termográfiás méréstechnika eredményét befolyásoló tényezők alapos ismerete. 


\section{Szakirodalmi hivatkozások}

[1] Haraszti F.: The bases of corrosion's investigation. In: A XXI. Fiatal műszakiak tudományos ülésszak előadásai, Kolozsvár, Románia, Műszaki Tudományos Közlemények 5. (2016) 185-188. https://doi.org/10.33895/mtk-2016.05.37

[2] Budó Á.: Kísérleti Fizika II. Tankönyvkiadó, Budapest, 1971.

[3] Wellons M.: The Stefan-Boltzmann Law. Physics Department, The College of Wooster, Wooster, Ohio 44691, USA (Dated: May 9, 2007)

[4] Professzionális Ipari Méréstechnika, (2017.02.15.) http://www.pim-kft.hu (2017.02.15.)
[5] Villanyszerelők Lapja, (2017.02.22.) www.villanylap.hu

[6] Haraszti F.: Corrosion investigation of steel samples. In: A XXI. Fiatal műszakiak tudományos ülésszak előadásai, Kolozsvár, Románia, Műszaki Tudományos Közlemények 5. (2016) 189-192. https://doi.org/10.33895/mtk-2016.05.38

[7] Kovács K.: Korróziós alapfogalmak. Műszaki Könyvkiadó, Budapest, 1965.

[8] Kovács-Coskun T., Völgyi B., Sikari-Nágl I.: Kontaktkorróziós jelenség tanulmányozása acél alumínium párosításánál. EME kiadó, Kolozsvár, 2013, 201-204.

[9] Rachne E.: Termográfia elmélet és gyakorlati méréstechnika. Invest-Marketing Bt., 2018. 